\title{
Undergraduate Students' Self-Efficacy Strategies in Writing Academic Papers
}

\author{
Anne Yustica Pramesti Sumarsono \\ Universitas Sanata Dharma, Indonesia \\ Email: yusticaanne02@gmail.com \\ Concilianus Laos Mbato \\ Universitas Sanata Dharma, Indonesia \\ Email: cons@usd.ac.id
}

\begin{abstract}
This study explored the writing self-efficacy of English education undergraduates at Sanata Dharma University, Yogyakarta. Nowadays, many students still have not used self-efficacy in their studies. Consequently, they may encounter difficulties when working on tasks. As a result, the scores obtained are not the highest. Which may make them lack the motivation to learn. The purpose of this research was to determine the application of self-efficacy in writing works for the undergraduate course of English Education at Sanata Dharma University. The research question was: How can undergraduate students of the English Education Study Program manage self-efficacy and writing anxiety to complete the academic writing class? This research adopted qualitative methods making use of the Likert scale and interviews. The questionnaire was distributed to Sanata Dharma University's undergraduates who had received English courses in reading literary works. The results show that undergraduates have a high sense of self-efficacy, can complete academic writing on time, and we are motivated by their internal and surrounding environments.
\end{abstract}

Keywords: academic writing, qualitative method, self-efficacy, undergraduate students

\section{INTRODUCTION}

Writing has attracted the attention of researchers to a large extent because it is an indispensable skill to help learn any language. Without it, no further education would be possible (Shangarfan and Mamipour, 2011). For most people, the writing process is difficult. This takes a lot of time and requires too much attention. Besides, writing skills are particularly important for EFL (English as a Foreign Language) students because those are the main factor in achieving successful academic performance in an educational environment. However, learning to write and writing successfully as EFL students are usually problematic. In most cases, students often encounter some difficulties when writing. Moreover, due to the need to follow various instructions, they may find it difficult to do the task.

Education is an important role in the millennial generation. Education is a conscious and planned effort aimed at creating a learning atmosphere and learning process. Thus, students can actively develop their potential and fully develop the religious spiritual power, self-control, individuality, sublime character, skills, intelligence, and wisdom needed by themselves and the society (SISDIKNAS No. 20 of 2003). Based on this understanding, it is clear that education enables students to develop their potential and develop skills that can be used when socializing. Not only at the high school level, but higher education students are also required to develop their potential, life skills, as well as academic abilities. The success of students in sharing their potential and balancing between academic and nonacademic activities can be seen from their academic achievements. Based on Setiawan (2000), academic achievement is an individual learning effort that can show a degree of success in achieving goals. In the learning process in school or college, academic achievements focus on the 
students' grades. In measuring the learning achievement, the academic scores can be seen from the cognitive aspect to evaluate the mastery of knowledge. The current researchers attempted to investigate how undergraduate students could complete academic writing on time making use of self-efficacy.

One of the subjects taught at school is English. As EFL students in the English Education study program, students should master the four English skills, one of which is writing. Writing gives the opportunity for students to express thoughts and synthesize multiple points of view by considering the persuasive communication that emerges from realities that they can use to make good writing (Crowhurst, 1990). Accordingly, being able to compose texts is a basic ability for scholastic and expert achievement. Undoubtedly, college freshmen' writing abilities are among the best indicators of scholastic achievement (Geiser and Studley, 2001) and even outside the scholarly community, composing aptitudes are significant and a signature trait of expert capability (Light 2001). In that capacity, building up a superior comprehension of good and helpless composing is a significant goal, both for hypothetical and applied reasons. Based on this conception, EFL students should improve their writing skills especially in academic writing which is the compulsory class to graduate from college. Wijaya and Mbato (2020) stated that to produce more qualified EFL students, there should be a large gap between the desires of teachers and students when starting the scientific writing process so that students will perceive seriousness. Constraints in completing academic writing assignments include lack of motivation, writing nervousness, and unclear objectives in the writing elements.

Students in Indonesia who study English must graduate with good grades and must work hard to improve their writing skills. Writing is a daunting activity, especially for second language/foreign language learners but they must master this skill to achieve excellent results in content courses (especially higher education level). Meanwhile, the requirement for completing undergraduate education is to write academic papers, though sometimes students are not able to write good papers. Mullen (2006) states that most academics see fresh graduate students as those having advanced writing skills and therefore in no need for extensive guidance. In different words, the students got trouble in utilizing syntax and pick the jargon (Pratiwi, Rukmini, \& Faridi (2017). Therefore, having that in mind, students must gain self-efficacy to encourage them in overcoming unexpected and difficult things.

Writing is the most challenging and complex skill in learning a subsequent language. It depends on the utilization of vital language with underlying exactness and correspondence principles (Dar and Khan, 2015; Hyland, 2003; Mahboob, 2014). Writing anxiety is the overall tactile factor that interferes with or prevents the creative cycle and is followed by a reluctance to write and distorted clarification. For example, "journalists are taken to an uncreated world" and "great writers are considered immoral". "Development and inspiration" exacerbate the stress and unfriendly impact of composition (Shunk, 2009). As a passionate factor, composing tension can carry pressing factors and strain to students and make them surrender any composition (Katranc1, 2015; Blasco, 2016). Scientists for the most part allude to the affliction brought about by nervousness. Writing is an intellectual interaction that can test memory, thinking abilities, and verbal orders to effectively communicate reflection (Kellogg, 2001) because proficient writing shows the success of second language learning (Geiser \& Studley, 2002; Hyland, 2003; McCutchen, 1984; Nickerson, Perkins, \& Smith, 2014). Diasti and Mbato (2020) state that lecturers ask the students to work individually in the academic writing class. This means that students are expected to cultivate skills to manage their anxiety in writing. Therefore, in the past two decades, learning to write has become very important due to two factors: it is used as a tool for effective communication of ideas (Graham \& Perin, 2007; Haider, 2012; Hyland, 2003).

When students study academic writing, they sometimes feel scared and lack confidence. At such times, the role of the lecturer is very important for 
boosting students' confidence and creating a positive learning atmosphere (such as motivating students and setting an example for students). Lecturers are relied upon to have a connection between showing methods and creativity in educating writing (Ghufron \& Hawa, 2015). Bandura (1960) pointed out that Social Cognitive Theory (SCT) is a kind of learning in a social environment of dynamic interaction and mutual interaction between person, environment, and behaviour. The characteristics of the social cognitive theory are to emphasize social influence and to strengthen external and internal society. Bandura (1986) asserts that a supportive learning environment can make students feel fun in learning because all environmental factors can provide positive spirits. According to Schunk (1995), a good sense of self-efficacy will guide students to reduce grade anxiety because they can determine their learning goals and make more efforts to achieve them. Furthermore, teachers must be able to help students determine learning goals so that students can develop self-efficacy. Besides, students will also encounter difficulties in achieving these goals. If students can use their selfefficacy well, they will attain goals more easily. Bandura (2001) pointed out that the core characteristics of private agency solve the question of what it means to be humans, which includes intentionality, forward-looking, self-reactivity, and self-reflection. The first one is deliberate. According to Bandura (2001), agency refers to purposeful action. Individuals can choose to show a tolerant attitude, or use self-influence to show the opposite behaviour. The purpose is to indicate the operation to be performed in the future. The second one is far-sighted. People construct result expectations based on the conditional relationship between the observed surrounding environmental events and the results of actions (Bandura 1986). Thirdly, the self-reaction ability of a nation must not only be limited to being a planner and thinker but also a motivator and self-organizer. Bandura (2001) pointed out that after adopting intentions and action plans, people cannot simply sit down and wait for a suitable performance to appear.
Therefore, institutions are not only involved in the ability to make decisions and take action but also to provide appropriate forms of action and the ability to incentivize and organize their implementation. These include self-monitoring, self-direction of performance through personal standards, and self-correcting responses (Bandura 1986, 1991b). The last one is self-reflection. People are not only agents of action but also self-checkers of their functions. Bandura (2001) pointed out that reflecting on one's metacognitive ability and the sufficiency of thoughts and behaviours are the core characteristics that distinguish humans from subjects. Through reflective self-awareness, people can evaluate their motivations, values, and the meaning of life pursuits. It is in this higher level of self-reflection that the individual resolves the conflict in motivation and persuasion and chooses to act for others (Bandura 1986).

A person sometimes has a high belief in selfefficacy; they will feel a strong sense of happiness and high self-esteem (Bandura, 1997; Flammer, 1990). As an alternative to the view that individual behaviour is entirely a response to the external environment, this basic framework regards the individual as being proactive, self-reflective, selfregulating, and motivating through subjective assessment of their abilities (Bandura, 1997). They take the initiative to do something, do your best when necessary, and insist on doing it well. As long as it is good, it can produce positive results. If someone feels stressed, self-efficacy can help relieve stress. Bandura (1997) pointed out that if a person does something ambitiously, self-efficacy can also cause stress. Besides, self-efficacy can have a positive impact on daily life. It will also increase academic performance in school. On the other hand, perceived failure will also hinder selfefficacy. Each person can determine his/her level of self-efficacy. Bong and Skaalvik (2003) pointed out that academic self-concept can indicate a certain academic field, and self-efficacy can indicate selfbelief that is considered successful when someone completes certain tasks. Pajares (2001) pointed out that if students study the same material, selfefficacy can indicate someone's confidence in completing the task. Therefore, students who have 
a good sense of self-efficacy can easily complete tasks, especially English reading practices, and can understand what is being discussed. Wuepper (2017) pointed out that PSE is domain-specific and different from a more general concept. Most people have higher PSE in some domains and lower PSE in others. In some areas, the level of PSE has practical and measurable effects. People with higher PSE will have higher ambitions, a sense of hard work, and will worry less about their efforts.

Self-efficacy in the academic field can be interpreted as the ability of students to carry out and organize activities properly. When someone believes in the abilities he has, the business he runs will also get bigger and more active. This is done to prove his ability to help in doing a task and facing obstacles when completing it. While Chairiyati (2013) conducted quantitative research, this research will employ a qualitative method to obtain objective test results. Chairiyati (2013) described the relationship between self-efficacy and academic self-concept and academic achievement. To fill in the gap, the research would examine students' self-efficacy in working on academic writings on an ongoing basis. This research proposed one research problem, namely, How can undergraduate students of English Education in Yogyakarta manage self-efficacy and writing anxiety to complete the academic writing class?

\section{METHODOLOGY}

This research used a qualitative method. Gunawan (2013) pointed out that qualitative research is the study of specific links to social relations related to the diverse facts of the lifeworld. Qualitative research aims to understand human behaviour from the perspectives of the actor's authority (how the actor perceives and interprets activities based on its creation). Qualitative research is a research method used to express government and private sector matters as well as social issues relating to youth, women, sports, art, and cultural organizations. It can be used as a policy to achieve common welfare (Gunawan, 2013: 80-81). The subjects of this research were eighth and seventhsemester students who had already taken the research proposal class in the English Education Department of Sanata Dharma University, Yogyakarta. Because of the pandemic Covid-19, many participants could not participate in this research. Only eight students agreed to participate. The method of retrieving data was to provide participants with a questionnaire that was distributed through Google Forms which could be filled out according to their situation. The reason for choosing participants with those criteria was to prepare them to continue writing their thesis and academic papers in the form of a thesis proposal. The researchers wanted to get their perspectives on self-efficacy in completing the final year project from the beginning of writing a thesis proposal.

For data collection techniques, the researchers distributed a questionnaire consisting of 10 open-ended questions and interviewed English Education undergraduate students' perceptions of self-efficacy in writing preparation for the final year project. In the questionnaire, some questions contained the main principles covering the entire research question. The questionnaire consisted of 10 questions about the main topics in the research. Not only did the questionnaire collect respondents' responses but the interview also clarified the respondents' intentions and provided reasons as per the aims and objectives of the study. The researchers used an unstructured interview. An interview is a data collection technique to find problems more openly where the party is invited to be asked for information, opinions, and ideas. Researchers in conducting interviews should listen carefully and record what is explained by the informant (Sugiyono, 2008). In this interview, the researchers collected data from parents of autistic children and English language teachers who taught these autistic children. This interview was carried out until the researchers got thorough information. In analyzing data, four activities including data reduction, data display, conclusion, and verification were done (Sugiyono, 2014).

Data reduction was carried out by summarizing the raw field notes and selecting the main points. Besides, the researchers also rechecked and made coding to each unit so that 
the source could be traced. Second, data display was done by displaying the overall results of the study in the form of descriptions, charts, and matrices. Afterwards, the researcher drew conclusions based on the data obtained. Conclusions in qualitative research were expected to be new findings that have never existed before. Furthermore, the researchers submitted a complete research report. At that point, the questionnaire data will be investigated utilizing descriptive statistical analysis. The rate calculation equation is as follows.

$$
\Sigma x / \Sigma \text { n. } 100 \%
$$

where

$\Sigma x$ : Number of the voters

$\Sigma \mathrm{n}$ : Number of all participants

\section{RESULTS AND DISCUSSIONS}

This part is enacted to summarize all the findings obtained through the Likert-scale questionnaire and interview about undergraduate students' perceptions of their self-efficacy in academic writings. There are two findings that the researcher found. The first is related to the influence of external and internal factors that maintain students' self-efficacy during academic writing activities. The second finding emphasizes the importance of increasing self-efficacy in leading students to succeed in academic writing. Each finding is presented in the following table accompanied by several important quotes from the interview results, related findings from previous research, and related theories to provide in-depth discussion.

Table 1. The Questionnaire Results

\begin{tabular}{|c|c|c|c|c|c|}
\hline Statements & $\begin{array}{l}\text { Strongly } \\
\text { Disagree }\end{array}$ & Disagree & Neutral & Agree & $\begin{array}{c}\text { Strongly } \\
\text { Agree }\end{array}$ \\
\hline $\begin{array}{l}\text { As an undergraduate in } \\
\text { English education, I think } \\
\text { I must master academic } \\
\text { writing skills to make me } \\
\text { look more academic. }\end{array}$ & - & - & $\begin{array}{c}2 \\
(25 \%)\end{array}$ & $\begin{array}{c}5 \\
(62.5 \%)\end{array}$ & $\begin{array}{c}1 \\
(12.5 \%)\end{array}$ \\
\hline $\begin{array}{l}\text { I can overcome the } \\
\text { anxiety of writing } \\
\text { because I believe I have } \\
\text { enough ability to produce } \\
\text { qualified academic } \\
\text { writing products. }\end{array}$ & - & - & $\begin{array}{c}4 \\
(50 \%)\end{array}$ & $\begin{array}{c}2 \\
(25 \%)\end{array}$ & $\begin{array}{c}2 \\
(25 \%)\end{array}$ \\
\hline $\begin{array}{l}\text { By observing the } \\
\text { academic writing success } \\
\text { of my colleagues, I am } \\
\text { deeply eager to improve } \\
\text { my academic writing } \\
\text { skills. }\end{array}$ & - & - & $\begin{array}{c}1 \\
(12.5 \%)\end{array}$ & $\begin{array}{c}5 \\
(62.5 \%)\end{array}$ & $\begin{array}{c}2 \\
(25 \%)\end{array}$ \\
\hline $\begin{array}{l}\text { When my academic } \\
\text { writing product is } \\
\text { evaluated and accepted } \\
\text { by my academic } \\
\text { consultant, I will be more } \\
\text { likely to succeed in } \\
\text { academic writing. }\end{array}$ & - & - & $\begin{array}{c}3 \\
(37.5 \%)\end{array}$ & $\begin{array}{c}3 \\
(37.5 \%)\end{array}$ & $\begin{array}{c}2 \\
(25 \%)\end{array}$ \\
\hline $\begin{array}{l}\text { If my academic advisors } \\
\text { and colleagues always }\end{array}$ & - & - & $\begin{array}{c}1 \\
(12.5 \%)\end{array}$ & $\begin{array}{c}6 \\
(75 \%)\end{array}$ & $\begin{array}{c}1 \\
(12.5 \%)\end{array}$ \\
\hline
\end{tabular}




\begin{tabular}{|c|c|c|c|c|c|}
\hline $\begin{array}{l}\text { encourage me, I will be } \\
\text { more confident to } \\
\text { complete my academic } \\
\text { writing project. }\end{array}$ & & & & & \\
\hline $\begin{array}{l}\text { When I classify academic } \\
\text { writing projects as fun } \\
\text { and interesting learning } \\
\text { activities, I believe I will } \\
\text { be able to produce } \\
\text { excellent writing } \\
\text { products. }\end{array}$ & - & - & $\begin{array}{c}3 \\
(37.5 \%)\end{array}$ & $\begin{array}{c}4 \\
(50 \%)\end{array}$ & $\begin{array}{c}1 \\
(12.5 \%)\end{array}$ \\
\hline $\begin{array}{l}\text { When I can build a higher } \\
\text { sense of self-efficacy in } \\
\text { academic writing, I will } \\
\text { find many strategies to } \\
\text { complete writing tasks in } \\
\text { a challenging writing } \\
\text { environment. }\end{array}$ & - & - & $\begin{array}{c}1 \\
(12.5 \%)\end{array}$ & $\begin{array}{c}5 \\
(62.5 \%)\end{array}$ & $\begin{array}{c}2 \\
(25 \%)\end{array}$ \\
\hline $\begin{array}{l}\text { I am confident that if I } \\
\text { insist on achieving my } \\
\text { goals through writing } \\
\text { projects, I will be able to } \\
\text { write more qualified } \\
\text { academic works. }\end{array}$ & - & - & $\begin{array}{c}1 \\
(12.5 \%)\end{array}$ & $\begin{array}{c}6 \\
(75 \%)\end{array}$ & $\begin{array}{c}1 \\
(12.5 \%)\end{array}$ \\
\hline $\begin{array}{l}\text { I can stay calm, although } \\
\text { I will encounter many } \\
\text { writing obstacles in the } \\
\text { academic writing process } \\
\text { because I have done all } \\
\text { my hard work, } \\
\text { dedication and } \\
\text { perseverance to finish my } \\
\text { writing. }\end{array}$ & - & - & $\begin{array}{c}2 \\
(25 \%)\end{array}$ & $\begin{array}{c}5 \\
(62.5 \%)\end{array}$ & $\begin{array}{c}1 \\
(12.5 \%)\end{array}$ \\
\hline $\begin{array}{l}\text { I am convinced that if my } \\
\text { academic advisor also } \\
\text { goes all out in the writing } \\
\text { process, goes all out to } \\
\text { provide me with } \\
\text { guidance, then the } \\
\text { academic writing } \\
\text { activities will be more } \\
\text { feasible and enjoyable. }\end{array}$ & - & - & $\begin{array}{c}2 \\
(25 \%)\end{array}$ & $\begin{array}{c}4 \\
(50 \%)\end{array}$ & $\begin{array}{c}2 \\
(25 \%)\end{array}$ \\
\hline
\end{tabular}

Table 4.1 above shows the results of ten statements that determine students' self-efficacy in academic writing. The first statement shows that one student $(12.5 \%)$ chose "strongly agree" and five undergraduate students (62.5\%) chose "agree". Based on these findings, it can be concluded that most undergraduates believe that academic writing is very important for academicians to 
make them look more scientific in their academic life. This finding is in line with the theory of writing that scientific writing and other elements of professional development are more academic in nature or contain scientific value than other activities that require a high degree of creativity (Sudjana, 1991: 6). Based on the interview, most students have good self-efficacy in writing papers. The reasons are that they know how to reach their goals in writing papers due to strong determination, and they can manage their time very well to do their best and successfully write papers.

In the second statement, two students (25\%) chose "strongly agree" and two students (25\%) chose "agree". It can be concluded that most undergraduates have more control over writing anxiety because they firmly believe in their writing skills. This finding corresponds to the previous study by Dar \& Khan (2015). They found that writing is the most challenging skill in learning a second language. It is based on the use of precise strategic language with structural accuracy and communication potential. According to the interview, the way and purpose of writing papers are that students can use self-efficacy to motivate themselves. Although it is difficult, they still think they can do it. Then, they will confidently realize their writing skills and continue to make every effort.

In the third statement, two students (25\%) chose "strongly agree" and five students (62,5\%) chose "agree." Regarding these findings, it can be said that a large part of undergraduates can excel in academic writing because they are willing to imitate the effective writing strategies of other learning partners and become excellent academic writers. This finding is in line with Moran and McMaster (2009) research results. They found that verbal persuasion will be useful and meaningful for future writing learning motivation because language teachers can design renewable learning strategies that are compatible with EFL students' writing skills so that they can instill a higher level of self-efficacy. According to the interview that the researchers did, some factors can affect students' self-efficacy in academic writing: they have social role models that can affect someone's self-efficacy by seeing other people's success, they have ambition, passion, and goals in the academic life, and they feel confident to improve their skills in writing.

The fourth statement shows that two students $(25 \%)$ chose "strongly agree" and three students $(37.5 \%)$ chose "agree". These findings indicate that if most undergraduates have experienced these positive learning nuances in the past, they can repeat similar academic writing achievements. The fourth finding is congruent with the research findings of Mbato \& Cendra (2019). They found that if a thesis instructor always gives students meaningful and continuous support, then their motivation to write a thesis will be continuously cultivated. Based on the interview, the contributions of the academic supervisor towards students' writing tasks are to remind them to write an accurate and credible paper, to search information from official sites, educational institutes, and agencies (e.g., The Jakarta Post, Mendeley, Google Scholar, the university's library), and to give feedback and suggestions so the students can improve their writing skills and reduce their mistakes.

The fifth statement shows that one student $(12,5 \%)$ chose "strongly agree" and six students (75\%) chose "agree". Regarding these findings, students will be more confident in completing the paper if the supervisor and their friends always give words of encouragement. Based on Bandura's (1986) theory of reciprocal determination and the concept of agency, people's behaviour and the environment will influence each other; the ability of individuals to use agents is premised on their awareness of their behaviour and the ability to formulate control and organizational strategies. According to the interview, the significance of friends in academic writing is to encourage each other to always write in the best way possible and to exchange information about how to outline the paper.

The sixth statement shows that one student $(12.5 \%)$ chose "strongly agree" and four students $(50 \%)$ chose "agree". It means that when students write, they look for topics that are relevant to their 
lives, interesting to research so that they can produce good writing products along the way. That is in line with the opinion of Graham \& Perin (2007that technology can cultivate students' writing interest and motivation, and improve their writing skills. Similarly, some metacognitive, cognitive, and social-emotional strategies can also be used to enable students to understand and practice the writing process (O'Malley \& Chamot, 1990). Also, according to the interviews, the participants' strategies for academic writing were to select topics, create an outline, research the topics, try to use appropriate sentence structure, and pay attention to punctuation, writing style, and grammar. They also made a note to record the key points and read journals to find good resources. On the other hand, Keen (2017) explains that currently, most English teachers in primary and secondary schools use a product-based approach and genre-based strategies. Sometimes the teachers use one or two elements of the process method (usually from the pre-activity) to teach writing. They do not correct spelling, punctuation, and expressions.

The seventh statement shows that two undergraduate students (25\%) chose "strongly agree" and five undergraduate students (62.5\%) chose "agree". This means that students can find suitable strategies in academic writing which can increase their sense of self-efficacy to complete the challenging writing assignments in writing classes. This is consistent with previous studies by Quintero's (2008) and Nik, Hamzah and Rafidee (2010). They claim that students are struggling with the structural components of English because inappropriate structures may complicate the content and make readers hardly understand the text through the participation of psychological processes (Quintero, 2008; Nik, Hamzah, and Rafidee, 2010). According to the interview results, the way to improve academic writing skills is that students need to pay attention to basic elements such as grammar, language style, and punctuation. After that, they need to use the correct vocabulary.

The eighth statement shows that one undergraduate student (12.5\%) chose "strongly agree" and six undergraduate students (75\%) chose "agree". This means students have to work hard to be able to produce high-quality academic papers and face many challenges along the way. That is in line with the opinion of Bilal et al. (2013) that students may face many challenges, such as the lack of reading motivation and the reluctance to practice. Student writers may turn ideas into the text to face psychological, cognitive, social, and language problems. The interview reveals that students can practice writing and reading.

The ninth statement shows that one undergraduate student $(12.5 \%)$ chose "strongly agree" and five undergraduate students (62.5\%) chose "agree". It shows that students can overcome the challenges in academic writing activities because they already have good self-efficacy. Students can pass these challenges calmly and remain enthusiastic in carrying out academic writing activities. This is in line with the views of Haider (2012) and Hyland (2003) that student writers face various writing problems at different stages of learning. According to the interview, students continue to write to cope with writing anxiety even if they are unwilling. They think that practicing writing is the best way to overcome writing anxiety. They should be confident and motivate themselves, and then improve their grammar and vocabulary.

The last statement shows that two undergraduate students (25\%) chose "strongly agree" and four undergraduate students (50\%) chose "agree". It means that academic supervisors play an important role in the students' academic writing process. If the academic supervisor tries his best to help, the students will also have good progress. This is in line with the opinion of Ahmad et al. (2013) that lack of confidence in students is also caused by the fact that the teaching strategies do not conform to the students' learning style and cultural background. Based on the interview, there are various answers about writing an academic paper. Student A said that writing was a fun activity. Before she started writing, she always reads a lot of journals, e-books, and papers as her references. By reading books, she gained a lot of knowledge. Then, she thought that the paper 
became more credible and accurate because she wrote her paper based on credible and accurate references.

The results of this study indicate that the self-efficacy variable that plays a role in influencing students' interest in completing the academic writing class is congruent with the research results of Warsito (2004). Students' academic achievement is more due to the direct causality of self-efficacy rather than the indirect causality of academic self-concept. The self-efficacy possessed by students in compiling academic writing is caused by the enthusiasm in themselves, as well as environmental factors that work well together such as classmates who help each other and also academic supervisors who provide feedback and encouragement to always give the best. The success factor of each individual can be felt when one has good self-efficacy. Therefore, every student needs to have good self-efficacy to be able to realize the goals that have been planned.

\section{CONCLUSION}

This research was conducted to find out how English education undergraduate students at a university in Yogyakarta apply self-efficacy in academic writing. The conclusion obtained is that students can complete academic writing well if they apply self-efficacy in themselves. Besides, encouragement from the surrounding also affects how good self-efficacy one has, such as support from classmates and academic supervisors. Using good reading and writing techniques, consistency in searching for relevant literature and practicing to write are ways to make academic writing easier. Due to the pandemic that is still happening, the authors only use a limited number of students for the interview and questionnaire. This can be a drawback of this research. It is hoped that further research can use quantitative methods to strengthen the research data by involving a bigger number of participants. In addition, future researchers are expected to be able to research academic writing at the elementary level, such as basic writing where English education students usually get the course in the first semester. The reason why this is important to investigate is that many English education students deal with a problem at the beginning of college because they are not used to using English in their daily lives. Therefore, this can also affect the basic writing process.

\section{ACKNOWLEDGMENT}

First of all, I would like to commend the Almighty Lord Jesus Christ for his blessing throughout the writing process of the paper, to complete the research.

I want to thank my awed Mamah ESP Handayani for her love, prayers and caring for my future. Also, the endless love and endless prayers of my brother Antonius Vendhy; and my grandparents Mbah Sunyoto and Mbah Mintarsih. They are my motivation to complete this paper. They have always supported me and have been there throughout the entire process of writing my paper.

I would like to thank my aunt Ibu Sumarti Endah PMM and M.Kep for their help and support during the writing of this article. She always gives me a suggestion to improve my paper. She is like my second paper consultant, and I am lucky to have her. I would also like to thank my excellent lecturer Drs. Concilianus Laos Mbato, M.A., Ed.D. He always gives me motivation, guidance and advice to work hard to complete my paper. When we consulted in class, he provided us with the best service, cited his research examples, and reminded us to stay healthy and eat healthy food. I would also like to thank the undergraduates from batch 2016 to batch 2017 who helped me collect data and worked well together so that I can complete and complete this research on time. Last but not least, I would also like to thank my good friend Yakobos Tri Adi Susanto for their prayers, support, company and patience so that I still have the energy to complete this paper.

\section{REFERENCES}

Abderraouf, A. (2016). Investigating EFL Students' Writing Difficulties and Common Errors in Writing. University of Bejaia. (2020, December 6). 
Bandura, A. (1977). Self-efficacy: Toward a unifying theory of behavioral change. Psychological Review, 191-215.

Bandura, A. (1986). The explanatory and predictive scope of self-efficacy theory. Journal of Clinical and Social Psychology, 4, 359-373.

Bandura, A. (1997). Self-Efficacy: The Exercise of Control. W. H. Freeman and Company.

Bandura, A. (2001). Social cognitive theory: An agentic perspective. Annual Review of Psychology.

Bandura, A., Ross, D., \& Ross, S. A. (1961). Transmission of aggression through imitation of aggressive models. The Journal of Abnormal and Social Psychology, 63(3), 575-582.

Dar, M. F., \& Khan, I. (2015). Writing anxiety among public and private sectors Pakistani undergraduate university students. Pakistan Journal of Gender Studies, 10.

Diasti, K. S., \& Mbato, C. L. (2020). Exploring Undergraduate Students' Motivationregulation Strategies in Thesis Writing. Language Circle: Journal of Language and Literature, 14(2), 176-183.

Fareed, M., Ashraf, A., \& Bilal, M. (2016). ESL Learners' Writing Skills: Problems, Factors and Suggestions. Journal of Education $\mathcal{E}$ Social Sciences, 4(2), 83-94.

Flammer, A. (2015). Self-Efficacy. In International Encyclopedia of the Social $\mathcal{E}$ Behavioral Sciences: Second Edition (pp. 504-508). Elsevier Inc.

Ghufron, M. A., \& Hawa, M. (2015). The effect of collaborative writing technique in teaching argumentative essay writing viewed from the students'creativity. Language and Literature, 10, 1.

Graham, S., \& Perin, D. (2007). A meta-analysis of writing instruction for adolescent students. Journal of Educational Psychology, 99(3), 445.
Keen, J. (2017). Teaching the writing process. Changing English, 24(4), 372-385.

Mbato, C. L. (2020). Graduate Students' Perceptions on their Self-Efficacy in Writing Academic Papers. ELT Worldwide: Journal of English Language Teaching, 7(1), 31-41.

Mbato, C. L., \& Cendra, A. (2019). Efl undergraduate students' self-regulation in thesis writing: help-seeking and motivationregulation. JELE (Journal of English Language and Education), 5(1), 66-82.

Nik, Y. A., Sani, B. B., Kamaruzaman, M. N. B. W. C., Hasbollah, H. R. B., et al. (2010). The writing performance of undergraduates in the University of Technology, Mara, Terengganu, Malaysia. Journal of Languages and Culture, 1 (1), 8-14.

O'malley, J. M., O'Malley, M. J., Chamot, A. U., \& O'Malley, J. M. (1990). Learning strategies in second language acquisition. Cambridge University Press.

Pratiwi, Y. E., Rukmini, D., \& Faridi, A. (2017). The linguistic problems of students' competence in writing business letters. Journal of Language and Literature, 11(2), 117-126.

Quintero, L. M. (2008). Blogging: A way to foster EFL writing. Colombian Applied Linguistics Journal, 10(1), 7-49.

Rusdiana, A. (2019). Panduan Penulisan Artikel Jurnal Ilmiah.

Schunk, D. H. (1995). Self-Efficacy and Education and Instruction. In J. E. Maddux (Ed.), Self-

Efficacy, Adaptation, and Adjustment: Theory, Research, and Application (pp. 281303). Plenum Press.

Wijaya, K. F., \& Mbato, C. L. (2020). Graduate Students' Perceptions on Their Self-Efficacy in Writing Academic Paper. ELT Worldwide, 7(1). Wuepper, D., \& Lybbert, T. (2017). Perceived SelfEfficacy, Poverty, and Economic Development. Annual Review of Resource Economics, 9, 383-404. (2020, December 7). 